\title{
Glucose Intolerance in Uremia
}

\author{
QUANTIFICATION OF PANCREATIC BETA CELL SENSITIVITY \\ TO GLUCOSE AND TISSUE SENSITIVITY TO INSULIN
}

\author{
Ralph A. DeFronzo, Jordan D. Tobin, John W. Rowe, and Reubin Andres, The \\ Clinical Physiology Branch, Gerontology Research Center, National Institute \\ on Aging, National Institutes of Health, Baltimore City Hospitals, \\ Baltimore, Maryland 21224 and the Department of Internal Medicine, \\ Yale University School of Medicine, New Haven, Connecticut 06510
}

\begin{abstract}
A B S T R A C T The relative contributions of impaired insulin secretion and of tissue insensitivity to insulin to the carbohydrate intolerance of uremia were investigated in 10 chronically uremic subjects. Two types of glucose-clamp experiments were performed in each patient before and after $10 \mathrm{wk}$ of thrice weekly hemodialysis. In both types the blood glucose concentration was maintained at a constant level by the periodic adjustment of a variable glucose infusion with a negative feedback formula.
\end{abstract}

Hyperglycemic clamp. The blood glucose concentration was acutely raised and maintained $125 \mathrm{mg} / \mathrm{dl}$ above basal levels for $2 \mathrm{~h}$. Since the glucose concentration was held constant, the glucose infusion rate is an index of glucose metabolism (M). After dialysis $\mathbf{M}$ increased in all patients from an average of 4.23 to $6.30 \mathrm{mg} / \mathrm{kg}$ body wt per $\min (P<0.001)$. The plasma insulin responses (I) both pre- and postdialysis were biphasic with an early burst within the first 2-5 min, followed by a phase of gradually increasing insulin concentration. After dialysis the plasma insulin response diminished slightly. Consequently, the M/I ratio, an index of tissue sensitivity to endogenous insulin, increased postdialysis in all subjects by an average of $92 \%(P<0.01)$.

Euglycemic clamp. The plasma insulin concentration was acutely raised and maintained by a primecontinuous insulin infusion. The blood glucose concentration was held constant at the basal level by a variable glucose infusion as above. $\mathrm{M} / \mathrm{I}$ again is a measure of tissue sensitivity to insulin (exogenous) and increased in all patients postdialysis by an average of

Dr. DeFronzo's current address is the Renal Division, Department of Medicine, Yale New Haven Hospital, New Haven, Conn. 06510.

Received for publication 15 September 1975 and in revised form 31 March 1978.
57\% $(P<0.01)$. In two patients hepatic glucose production was measured with tritiated glucose during the euglycemic clamp and declined by $84 \%$ predialysis. A similar decrease (82\%) was observed postdialysis. Thus, both the hyperglycemic and euglycemic clamp techniques demonstrated tissue insensitivity to insulin to be the dominant carbohydrate defect in uremia. The surprising apparent lack of consistency in the change in beta cell response postdialysis is explained by the strong inverse correlation between beta cell sensitivity to glucose and tissue sensitivity to insulin $(r=-0.920 ; P<0.001)$. Those individuals who showed the most striking improvement in tissue sensitivity to insulin actually decreased their serum insulin response to hyperglycemia; those whose improvement in tissue sensitivity was more modest showed increases in beta cell responses.

\section{INTRODUCTION}

Abnormal carbohydrate metabolism in renal disease of diverse origin has been appreciated for over $60 \mathrm{yr}$, yet the mechanisms underlying this glucose intolerance remain unsettled. Decreased sensitivity of peripheral tissues to insulin seems well established. The results of forearm perfusion studies (1-3), the presence of elevated fasting immunoreactive insulin levels in uremia (4-9), and the delayed and diminished glucose response after exogenous insulin $(5,9-15)$ and tolbutamide $(4,9,11,14-16)$ indicate the presence of insulin resistance in the majority of patients with chronic renal failure. In contrast, conflicting reports have appeared on the plasma insulin response to intravenous and oral glucose in uremia. Although all investigators have found the late insulin response to be elevated (4-9, $11,17,18)$, the early insulin response has been reported to be normal $(4,5,7,17)$, increased $(6,9)$ or decreased $(11,18)$. In a recent review (19), we suggested that 
these apparent discrepancies could be resolved by postulating a balance between the effects of uremia on peripheral insulin antagonism and on pancreatic insulin secretion. If insulin synthesis and release were not impaired, glucose tolerance might be expected to remain normal despite peripheral insulin antagonism at the expense of hypersecretion of insulin. If, however, insulin antagonism were especially severe or if significant inhibition of insulin secretion were to be superimposed on a state of peripheral insulin resistance, glucose intolerance would result.

With the glucose clamp technique we have examined the relative contributions of impaired insulin secretion and tissue insensitivity to insulin in the genesis of uremia-induced carbohydrate intolerance.

\section{METHODS}

10 ambulatory volunteers with chronic renal disease ranging in age from 24 to $49 \mathrm{yr}$ were studied (Table I). There were six men and four women and all were within $20 \%$ of their desirable body weight. ${ }^{1}$ All subjects were free of gastro-

${ }^{1}$ The middle of the weight range for subjects of medium frame from the 1959 Metropolitan Life Insurance Company table for desirable weight was used. intestinal symptoms and were consuming a weight maintaining diet containing at least $200 \mathrm{~g}$ of carbohydrate per day for 3 days before study. Two patients (nos. 5 and 7) were on moderate protein restriction (40 g/day); for the 5 days immediately before study, however, the protein restriction was discontinued. There was no family history of diabetes mellitus; clinical evidence of diabetic retinopathy and neuropathy were absent; renal histology revealed no lesions suggestive of diabetic nephropathy. Liver function tests (serum glutamic-oxaloacetic transaminase, serum glutamicpyruvic transaminase, lactate dehydrogenase, alkaline phosphatase, bilirubin) were normal in all and there was no evidence of other endocrinologic disorders. 9 of 10 were on no medication for at least $2 \mathrm{wk}$ before study. One subject (no. 6) was taking guanethidine in a dose of $10 \mathrm{mg} /$ day, except on the morning of study. Pertinent clinical data for each subject are outlined in Table $I$. All had advanced renal failure of long duration.

Subjects 1-8 received the following four tests: oral glucose tolerance test ( $1.75 \mathrm{~g}$ of glucose/ $\mathrm{kg}$ body weight) (20), intravenous glucose tolerance test $(375 \mathrm{mg}$ of glucose $/ \mathrm{kg}$ body weight given over $5 \mathrm{~min}$ ), and hyperglycemic and insulin clamps as described below. Subjects 9 and 10 received only the insulin clamp study performed in conjunction with tritiated glucose to follow hepatic glucose production. Plasma glucose analyses were performed on venous samples from the oral and intravenous glucose tolerance tests with an automated ferricyanide reduction method (Technicon Instruments Corp., Tarrytown, N. Y.). Because of the increased amounts

TABLE I

Summary of Clinical and Laboratory Data

\begin{tabular}{|c|c|c|c|c|c|c|c|c|c|c|c|c|c|c|c|c|c|}
\hline \multirow{2}{*}{$\begin{array}{l}\mathrm{Pa}- \\
\text { tient }\end{array}$} & \multirow[b]{2}{*}{ Age } & \multirow[b]{2}{*}{ Sex } & \multirow[b]{2}{*}{ Height } & \multirow[b]{2}{*}{ Weight } & \multirow{2}{*}{$\begin{array}{l}\text { Obesity } \\
\text { index }\end{array}$} & \multirow[b]{2}{*}{ Diagnosis } & \multirow{2}{*}{$\begin{array}{l}\text { Duration } \\
\text { of renal } \\
\text { failure }\end{array}$} & \multicolumn{2}{|c|}{$\begin{array}{l}\text { Serum urea } \\
\text { nitrogen }\end{array}$} & \multicolumn{2}{|c|}{$\begin{array}{c}\text { Serum } \\
\text { creatinine }\end{array}$} & \multicolumn{2}{|c|}{ Blood pH } & \multicolumn{2}{|c|}{ Serum $\mathbf{K}^{+}$} & \multicolumn{2}{|c|}{$\begin{array}{c}\text { Serum } \\
\mathrm{Mg}^{++}\end{array}$} \\
\hline & & & & & & & & Pre & Post & Pre & Post & Pre & Post & Pre & Post & Pre & Post \\
\hline & & & $\mathrm{cm}$ & $k g$ & & & $y r$ & \multicolumn{2}{|c|}{$m g / d l$} & \multicolumn{2}{|c|}{$m g / d l$} & & & \multicolumn{2}{|c|}{ meq/liter } & \multicolumn{2}{|c|}{$m g / d l$} \\
\hline 1 & 44 & $\mathbf{F}$ & 160.0 & 50.2 & 0.94 & $\begin{array}{l}\text { Membranoproliferative } \\
\text { glomerulonephritis }\end{array}$ & 20 & 120 & 28 & 14.1 & 7.4 & 7.31 & 7.49 & 4.6 & 4.2 & 1.5 & 1.6 \\
\hline 2 & 25 & $\mathbf{M}$ & 172.1 & 80.0 & 1.21 & $\begin{array}{l}\text { Chronic glomerulo- } \\
\text { nephritis }\end{array}$ & 3 & 148 & 61 & 16.2 & 10.8 & 7.32 & 7.44 & 3.9 & 4.0 & 1.3 & 2.2 \\
\hline 3 & 49 & $\mathbf{F}$ & 160.0 & 47.1 & 0.89 & $\begin{array}{l}\text { Renal tuberculosis } \\
\text { Chronic pyelo- } \\
\text { nephritis }\end{array}$ & 10 & 79 & 46 & 11.3 & 11.2 & 7.42 & 7.47 & 5.2 & 5.5 & 1.8 & 2.5 \\
\hline 4 & 38 & $\mathbf{F}$ & 160.7 & 52.2 & 0.97 & $\begin{array}{l}\text { Membranous } \\
\text { glomerulonephritis }\end{array}$ & 2 & 90 & 28 & 11.2 & 6.0 & 7.36 & 7.47 & 4.7 & 3.8 & 1.8 & 2.0 \\
\hline 5 & 24 & $\mathbf{F}$ & 154.9 & 42.1 & 0.84 & Chronic pyelonephritis & 12 & 114 & 51 & 24.6 & 9.2 & 7.25 & 7.48 & 5.6 & 5.0 & 1.4 & 2.6 \\
\hline 6 & 39 & $\mathbf{M}$ & 171.4 & 83.1 & 1.18 & $\begin{array}{l}\text { Chronic glomerulo- } \\
\text { nephritis }\end{array}$ & 1.5 & 86 & 45 & 16.8 & 9.0 & 7.37 & 7.37 & 3.9 & 4.1 & 1.0 & 1.9 \\
\hline 7 & 32 & $\mathbf{M}$ & 176.5 & 72.1 & 1.04 & $\begin{array}{l}\text { Chronic glomerulo- } \\
\text { nephritis }\end{array}$ & 2.5 & 80 & 27 & 17.6 & 13.5 & 7.46 & 7.39 & 4.6 & 4.3 & 2.0 & 2.2 \\
\hline 8 & 43 & $\mathbf{M}$ & 182.9 & 69.2 & 0.93 & $\begin{array}{l}\text { Polycystic kidney } \\
\text { disease }\end{array}$ & 5 & 174 & 69 & 16.9 & 12.7 & 7.52 & 7.41 & 3.5 & 5.0 & 1.9 & 2.1 \\
\hline 9 & 35 & $\mathbf{M}$ & 168.9 & 76.4 & 1.19 & $\begin{array}{l}\text { Chronic glomerulo- } \\
\text { nephritis }\end{array}$ & 6 & 165 & 53 & 16.5 & 10.4 & 7.43 & 7.42 & 4.9 & 5.1 & 2.1 & 2.2 \\
\hline 10 & 24 & $\mathbf{M}$ & 165.1 & 55.0 & 0.91 & $\begin{array}{l}\text { Polycystic kidney } \\
\text { disease }\end{array}$ & 5 & 124 & 56 & 10.0 & 5.3 & 7.42 & 7.40 & 4.8 & 4.7 & 2.4 & 2.1 \\
\hline Mean & 35 & & 167.4 & 62.7 & 1.01 & & 7 & 116 & 46 & 15.5 & 9.5 & 7.39 & 7.43 & 4.7 & 4.6 & 1.7 & 2.1 \\
\hline SEM & 3 & & 2.8 & 4.7 & 0.04 & & 2 & 11 & 5 & 1.3 & 0.8 & 0.02 & 0.01 & 0.2 & 0.2 & 0.1 & 0.1 \\
\hline
\end{tabular}

* There was no significant difference in obesity index between the pre- and postdialysis studies.

† From first laboratory documentation of elevation in serum urea nitrogen and(or) serum creatinine. 
of nonglucose reducing substances in the plasma of uremic patients, a series of paired analyses of estimated glucose concentrations were performed on plasma samples by the ferricyanide method and by the glucose oxidase method (Glucostat, Beckman Instruments Corp., Fullerton, Calif.). Analyses were made on stored plasma samples from each of the subjects: 30 predialysis samples and 54 postdialysis samples were analyzed. In addition 64 samples from normal nonuremic volunteers were analyzed. The paired differences in estimated glucose concentration (ferricyanide minus glucose oxidase) averaged only $2 \mathrm{mg} / \mathrm{dl}$ in the normals in contrast to $27 \mathrm{mg} / \mathrm{dl}$ predialysis and $18 \mathrm{mg} / \mathrm{dl}$ postdialysis. Mean values in the eight patients predialysis ranged from 17 to $32 \mathrm{mg} / \mathrm{dl}$ and postdialysis ranged from 10 to $28 \mathrm{mg} / \mathrm{dl}$. Stored plasma was not available on all of the samples; therefore the measured mean value for nonglucose reducing substances pre- and postdialysis for each subject was used to correct the ferricyanide determinations which were made on all samples. Corrected values are presented in Table II. Responses to intravenous glucose were judged by computing the glucose decay constant calculated from glucose concentrations from 20 to $60 \mathrm{~min}$. All studies were performed at 8:00 a.m. after a 12-h overnight fast. The four studies were carried out on consecutive Tuesdays and Thursdays.

All but one patient (no. 3) were begun on thrice weekly hemodialysis within $3 \mathrm{wk}$ of the initial study period. 6 mo elapsed before patient no. 3 was begun on dialysis. After $10 \mathrm{wk}$ of thrice weekly hemodialysis (Monday, Wednesday, Friday) patients were again restudied on four consecutive Tuesdays and Thursdays. Laboratory data pre- and postdialysis are shown in Table I.

Before the hyperglycemic and insulin clamp studies a catheter was inserted under local xylocaine anesthesia into a brachial artery, arterial side of an arteriovenous shunt, or an arteriovenous fistula for blood sampling. A second catheter was inserted into an antecubital vein for insulin and glucose administration. After a control period of at least $\mathbf{3 0}$ min studies were performed as follows.

Hyperglycemic clamp. A priming infusion of glucose designed to raise the blood glucose concentration rapidly to $125 \mathrm{mg} / \mathrm{dl}$ above the fasting level was administered in a logarithmically falling manner over $15 \mathrm{~min}$. The arterial blood glucose concentration was determined every 5 min employing an automated ferricyanide method (Technicon Instruments Corp.) and the infusion rate of a $20 \%$ glucose

\section{TABLE II}

Oral Glucose Tolerance Test (OGTT) and Intravenous Glucose Tolerance Test (IVGTT) before and after 10 Wk of Hemodialysis

\begin{tabular}{cccccc}
\hline & \multicolumn{2}{c}{$\begin{array}{c}\text { OGTT, } \\
\text { Plasma glucose } \\
\text { conc. at 2 h }\end{array}$} & & \multicolumn{2}{c}{$\begin{array}{c}\text { IVGTT, } \\
\text { Decay constant, } K\end{array}$} \\
\cline { 2 - 7 } Patient & Pre & Post & & Pre & Post \\
\hline \multicolumn{2}{c}{ mg/dl } & & \multicolumn{2}{c}{ \%/min } \\
1 & 133 & 144 & & 1.40 & 1.55 \\
2 & 181 & 139 & & 2.33 & 1.65 \\
3 & 103 & 119 & & 1.93 & 2.17 \\
4 & 154 & 103 & & 1.71 & 2.23 \\
5 & 171 & 150 & & 0.90 & 0.97 \\
6 & 148 & 124 & & 0.86 & 2.36 \\
7 & 145 & 167 & & 0.44 & 0.67 \\
8 & 205 & 159 & 0.37 & 0.72 \\
\hline
\end{tabular}

solution was adjusted to maintain the blood glucose concentration constant at $125 \mathrm{mg} / \mathrm{dl}$ above the basal level.

The details of these periodic computations will be presented in a separate communication. Only the principal features of the technique are given here. (a) The glucose analytical delay time (from blood collection to readout of glucose concentration) was $4.5 \mathrm{~min}$. Each servo-correction of the glucose infusion rate was therefore based upon the subject's arterial glucose concentration 4 min previously. (b) The first servo-correction was made when the 10-min arterial blood glucose concentration became available, i.e., at $\mathbf{1 4 . 5}$ min. Subsequent corrections were made at 5-min intervals for the duration of the study $(120 \mathrm{~min})$. (c) The formula for the servo-correction is based upon the negative feedback principle. Thus, if the actual blood glucose concentration is greater than the goal, the glucose infusion rate is decreased, and vice versa. Of pertinence to this paper is the fact that the actual arterial blood glucose concentration was maintained within narrow limits of the specified goal (see Results). (d) Under these steady-state conditions of constant hyperglycemia the amount of glucose infused (milligrams per kilogram per minute) minus urinary losses (milligrams per kilogram per minute) is a measure of the glucose metabolized $(\mathrm{M}) ;^{2}$ this value is a function of the sensitivity of the tissues to insulin. Although the clamp method does essentially eliminate variance from subject to subject in blood glucose concentration, the plasma insulin levels are not the same in all subjects. In the euglycemic clamp (see below), insulin levels vary as a function of its metabolic clearance rate (MCR). In the hyperglycemic clamp, insulin levels vary not only as a function of MCR, but also as a function of the sensitivity of the beta cell to hyperglycemia. The fact that insulin levels vary makes it essential to "correct" the value for $M$ in some manner to take this variance into account. The simplest technique is to compute the ratio of $\mathrm{M}$ to the plasma insulin level, $I$, that is, to compute $M / I$. The underlying mathematical assumptions of such a computation are that $\mathbf{M}$ is linearly related to $I$ and that there is no intercept of $M$ on $I$. If either of these two assumptions is incorrect then a more complex formulation would be required. For example, computation of an $\mathrm{M} / \log \mathrm{I}$ ratio might be justified. Detailed information covering the range of plasma insulin concentrations pertinent to this study is not available at this time, and we have therefore chosen to correct for insulin concentration by the simplest possible technique, M/I. The mean insulin concentration in the 36 euglycemic and hyperglycemic clamp studies is $86 \mu \mathrm{U} / \mathrm{ml}$ (Tables III and IV) with a SD of 21. Within these reasonably narrow limits it is doubtful whether more complex formulations would significantly change the conclusions presented.

Eight normal weight (obesity index $=0.92-1.20$ ) male volunteers ranging in age from 22 to $47 \mathrm{yr}$ served as controls for the hyperglycemic clamp studies.

Euglycemic clamp. A prime plus continuous infusion of crystalline porcine insulin (Eli Lilly Co., Indianapolis, Ind.) was administered to attain constant hyperinsulinemia (21). The priming dose was administered in a logarithmically falling manner over $10 \mathrm{~min}$ at which time the continuous insulin infusion was begun. The total amount of insulin infused during the priming period was twice that infused during subsequent 10 -min intervals. The continuous insulin infusion $\left(40 \mathrm{mU} / \mathrm{m}^{2}\right.$ surface area per $\mathrm{min}$ ) was maintained for 70 min. $^{3}$ All experiments were continued for an addi-

${ }^{2}$ Abbreviations used in this paper: I, plasma insulin level; M, glucose metabolism; MCR, metabolic clearance rate.

${ }^{3}$ In patients 2,9 , and 10 the continuous infusion was extended to $120 \mathrm{~min}$. 
tional $40 \mathrm{~min}$ after the infusion was stopped. To prevent insulin absorption to glassware and to the plastic infusion apparatus, infusates were prepared with the addition of $2 \mathrm{ml}$ of the subject's whole blood per $50 \mathrm{ml}$ of infusate. Hypoglycemia with its attendant counter-regulatory responses was prevented by the glucose-clamp technique which was used to maintain each subject at his own basal arterial blood glucose concentration during and after insulin administration. The initial glucose infusion rate was $2.0 \mathrm{mg} / \mathrm{kg}$ body wt per min and was started $4 \mathrm{~min}$ after the insulin infusion was begun. At $10 \mathrm{~min}$ the glucose infusion was increased to $2.5-3.0 \mathrm{mg} / \mathrm{kg}$ per $\mathrm{min}$; these doses were empirically determined. The first servo-correction was made at $14.5 \mathrm{~min}$. Under the condition of constant euglycemia all of the glucose infused $(M)$ is metabolized and is thus a measure of the body's sensitivity to insulin.

During the euglycemia clamp in patients 9 and 10 , the effect of insulin on hepatic glucose production was examined with tritiated glucose labeled in the " 3 " position $\left(\left[{ }^{3} \mathrm{H}\right]\right.$ glucose). For $3 \mathrm{~h}$ before beginning the insulin infusion, each subject's glucose pool was labeled by a primed continuous infusion of $\left[{ }^{3} \mathrm{H}\right]$ glucose (New England Nuclear, Boston, Mass.). The labeled glucose was administered as an initial intravenous priming dose $(25 \mu \mathrm{Ci})$ followed immediately by a continuous intravenous infusion at a rate of $0.25 \mu \mathrm{Ci} / \mathrm{min}$. Plasma samples for determination of glucose specific activity were taken at 30 -min intervals for the first $2 \mathrm{~h}$ and at 10-15min intervals for the subsequent hour. A steady-state plateau of glucose specific activity was achieved in both subjects during the 3rd $\mathrm{h}$ of $\left[{ }^{3} \mathrm{H}\right]$ glucose infusion and this plateau value was used to calculate basal hepatic glucose production. After $3 \mathrm{~h}$ of continuous $\left[{ }^{3} \mathrm{H}\right]$ glucose infusion, the euglycemic clamp was begun as previously described and the continuous infusion of $\left[{ }^{3} \mathrm{H}\right]$ glucose was continued at the same rate. During the clamp study plasma samples for determination of glucose specific activity were drawn every $15 \mathrm{~min}$ for the first $90 \mathrm{~min}$ and every 5-10 min thereafter.

In the basal state glucose production was determined by dividing the $\left[{ }^{3} \mathrm{H}\right]$ glucose infusion rate (counts per minute) by the steady-state plateau of $\left[{ }^{3} \mathrm{H}\right]$ glucose specific activity achieved during the last hour of the control period. Since renal glucose production is negligible in the postabsorptive state, the rate of glucose appearance can be assumed to be equivalent to the rate of hepatic glucose production. After insulin-glucose administration (euglycemic clamp) a nonsteady-state condition in glucose specific activity exists and hepatic glucose production was calculated by Steele's equations in their derivative form (22) which permits the evaluation of continuous changes in the rates of glucose turnover. The value of 0.65 was used as the pool fraction in the present calculations (23). The determination of glucose turnover by the primed constant-infusion and pool fraction technique has recently been validated for both steady and nonsteady states (24). All calculations were performed with a program written in BASIC on a Hewlett-Packard desk computer (Hewlett-Packard Corp., Palo Alto, Calif.).

Methods for the determination of plasma immunoreactive insulin (21) and glucose specific activity (25) have previously been published. All serum chemistries (Table I) were determined by the routine clinical chemistry laboratory. All data are presented as the mean \pm SEM. Before participation the purpose and potential risks of the study were explained to all subjects and informed voluntary consent was obtained.

\section{RESULTS}

Oral and intravenous glucose tolerance tests (Table II). Oral glucose tolerance was poor in three of the subjects predialysis (nos. 2, 5, and 8), and each of these improved postdialysis to the normal range (20). Only two of the subjects had grossly abnormal performances on the intravenous glucose tolerance test. Both of these subjects improved postdialysis but performance remained poor.

Hyperglycemic clamp. Predialysis the fasting blood glucose concentration averaged $114 \pm 3 \mathrm{mg} / \mathrm{dl}$. During the period of sustained hyperglycemia the mean glucose concentration of the eight subjects was $238 \pm 4 \mathrm{mg} / \mathrm{dl}$. In the postdialysis studies the fasting

TABLE III

Glucose Metabolism (M) and Plasma Insulin Response during the Hyperglycemic Clamp (0-120 min) Pre- and Postdialysis*

\begin{tabular}{|c|c|c|c|c|c|c|c|}
\hline \multirow[b]{2}{*}{ Patient } & \multicolumn{3}{|c|}{ M } & \multicolumn{3}{|c|}{ Plasma insulin response } & \multirow{2}{*}{$\begin{array}{c}M / I \text { ratio } \\
\text { Increase postdialysis }\end{array}$} \\
\hline & Pre & Post & Increase & Pre & Post & Change & \\
\hline & & $\mathrm{mg} / \mathrm{kg} / \mathrm{min}$ & $\%$ & & $\mu U / m l$ & $\%$ & $\%$ \\
\hline 1 & 3.85 & 5.78 & 50 & 69 & 102 & +48 & 2 \\
\hline 2 & 4.32 & 5.62 & 30 & 117 & 96 & -18 & 59 \\
\hline 3 & 6.35 & 10.06 & 58 & 63 & 72 & +14 & 39 \\
\hline 4 & 4.70 & 7.32 & 56 & 89 & 88 & -1 & 58 \\
\hline 5 & 3.72 & 5.40 & 45 & 116 & 51 & -56 & 230 \\
\hline 6 & 4.50 & 6.97 & 55 & 91 & 106 & -16 & 33 \\
\hline 7 & 3.03 & 4.71 & 55 & 97 & 80 & -18 & 89 \\
\hline 8 & 3.35 & 4.50 & 34 & 75 & 44 & -41 & 129 \\
\hline Mean & 4.23 & 6.30 & 49 & 90 & 80 & -7 & 80 \\
\hline SEM & 0.36 & 0.64 & 3.9 & 20 & 23 & 12 & 25 \\
\hline$P$ & & & $<0.001$ & & & NS & $<0.02$ \\
\hline
\end{tabular}

* The values for $\mathrm{M}$ and for the plasma insulin concentration represent means for the entire $120 \mathrm{~min}$ of hyperglycemia. 


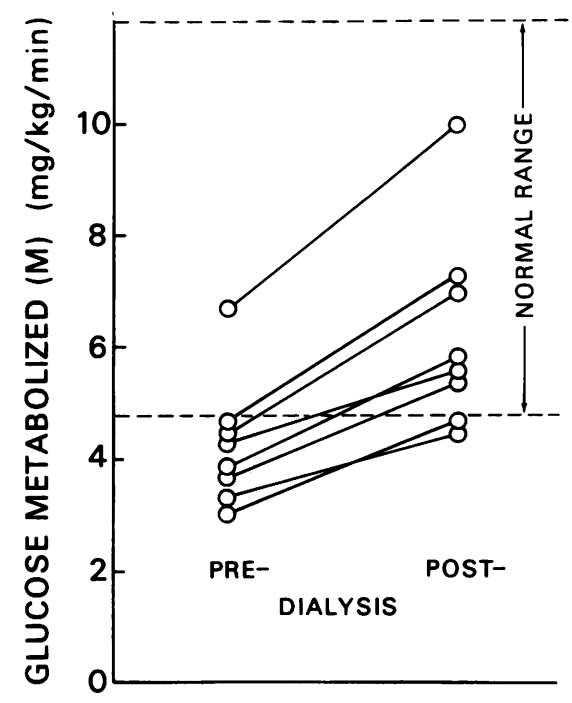

FIGURE 1 The effect of dialysis on glucose metabolized during the hyperglycemic clamp. Normal range was established from eight age- and obesity-matched volunteers.

blood glucose and steady-state hyperglycemic levels averaged $105 \pm 2$ and $229 \pm 3 \mathrm{mg} / \mathrm{dl}$, respectively. The stability of the blood glucose concentration during the period of hyperglycemia is reflected by the coefficient of variation which averaged $2.7 \pm 0.3$ during the predialysis studies and $3.2 \pm 0.3$ during the postdialysis studies.

The amount of glucose metabolized (M) during the 120-min period of sustained hyperglycemia increased in all eight subjects from an average of $4.23 \mathrm{mg} / \mathrm{kg}$ body wt per min predialysis to $6.30 \mathrm{mg} / \mathrm{kg}$ body wt per min postdialysis $(P<0.001)$. This represents an average increase of $49 \%$ (Table III). Predialysis seven of eight subjects were below the normal control range (Fig. 1). After dialysis, six of eight subjects fell within the normal range.

The plasma insulin concentration in response to the sustained hyperglycemia was biphasic with an early burst in insulin within the first 6 min followed by a gradually increasing phase of insulin release that lasted until the end of the study (Fig. 2). There was no difference in the early insulin response $(0-10 \mathrm{~min})$ between uremic subjects pre- and postdialysis and control subjects. After the initial peak, insulin values in uremics were significantly greater than controls $(P<0.01)$. After dialysis the late plasma insulin responses returned toward control values but the difference between pre- and post-dialysis values was not statistically significant. The fasting plasma insulin concentration was elevated predialysis $(14.8 \pm 1.4 \mu \mathrm{U} / \mathrm{ml})$ and remained unchanged postdialysis $(15.1 \pm 1.3 \mu \mathrm{U} /$ $\mathrm{ml})$. Both the pre- and postdialysis values were greater than controls $(P<0.02)$.

Tissue sensitivity to insulin (M/I ratio) postdialysis increased in all eight subjects by an average of $80 \pm 25 \%$ (Table III). All but subject no. 1 demonstrated $>30 \%$ increase in insulin sensitivity. In this patient the improvement in glucose metabolism (M) was entirely accounted for by an increase in insulin secretion (48\%) postdialysis.

Fig. 3 summarizes the four physiologic variables quantified by the hyperglycemic clamp technique. There was no difference in the hyperglycemic stimulus between pre- and postdialysis studies. The amount of

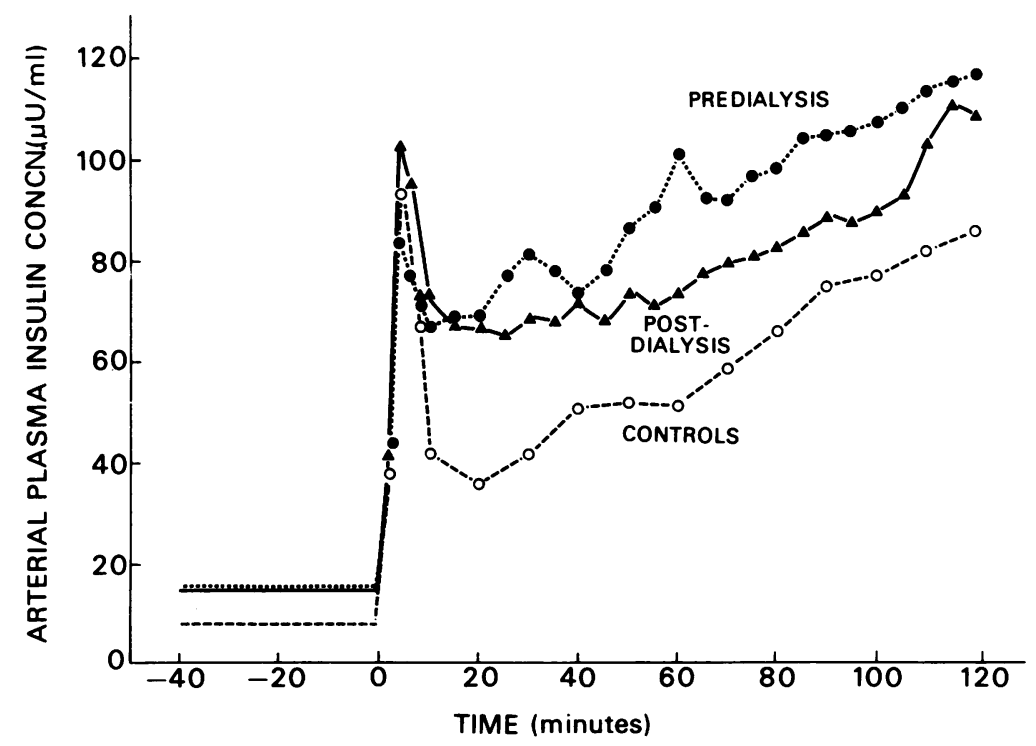

FIgURE 2 The time course of arterial plasma insulin concentration during the hyperglycemic clamp in uremic patients pre- and postdialysis and in control subjects. 


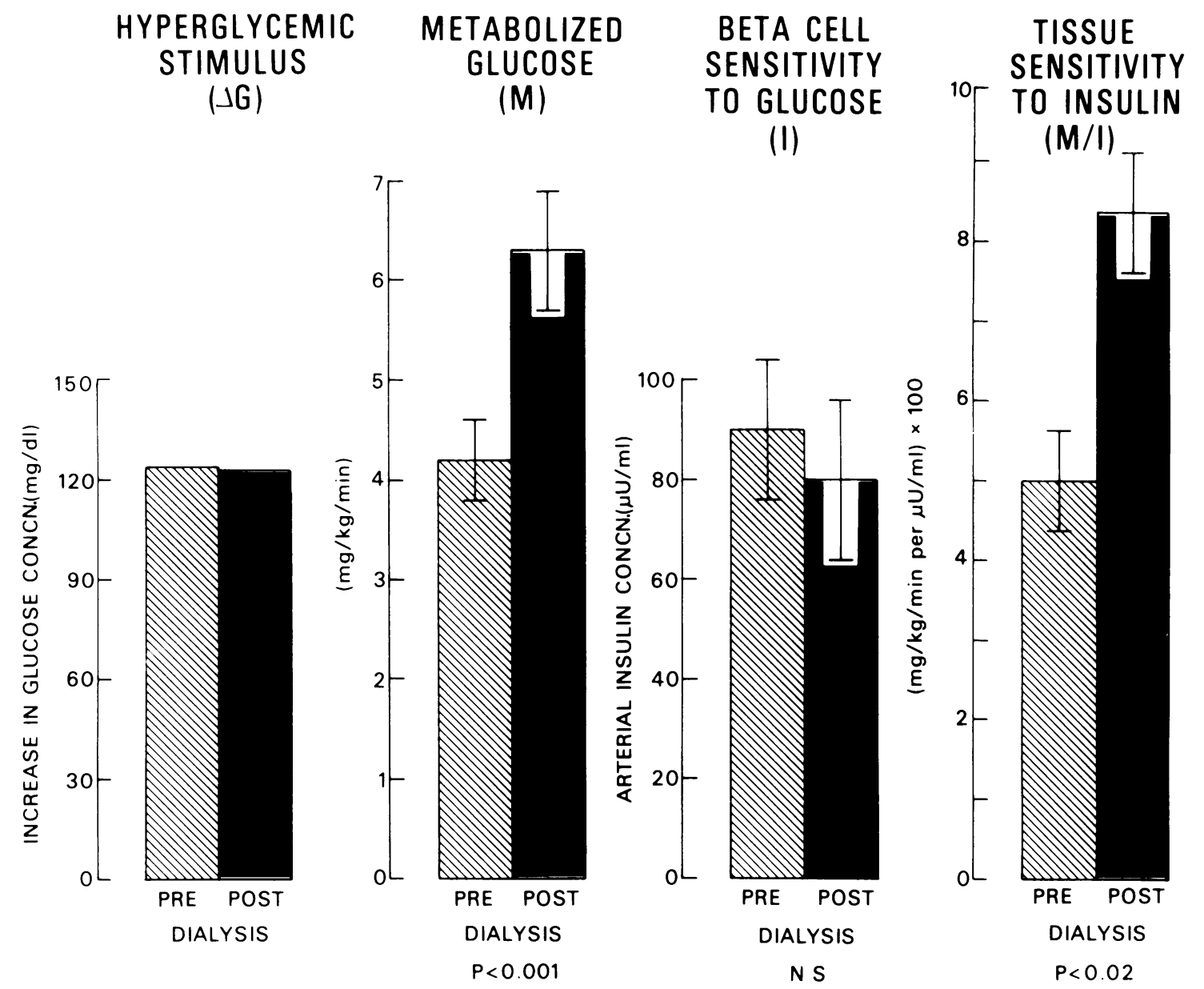

FIGURE 3 Summary of the physiologic variables quantified by the hyperglycemic clamp preand postdialysis. Means \pm SEM are presented; the SEM for the hyperglycemic stimuli are too small to be shown.

glucose metabolized $(\mathrm{M})$ increased significantly in all eight subjects postdialysis, yet insulin response diminished slightly. Consequently, the $\mathrm{M} / \mathrm{I}$ ratio increased by an average of $80 \%$, representing a marked improvement in the body's sensitivity to insulin.

Euglycemic clamp. The 10 uremic patients were studied pre- and postdialysis and were compared to eight age- and weight-matched normal control subjects. The insulin infusion resulted in a steady-state plasma insulin level $(20-80 \mathrm{~min})$ that averaged $110 \pm 4$ and $91 \pm 6 \mu \mathrm{U} / \mathrm{ml}$ pre- and postdialysis. The corresponding value in the control subjects was $87 \pm 4 \mu \mathrm{U} / \mathrm{ml}$. Predialysis levels were significantly higher than both postdialysis $(P<0.005$, paired analysis $)$ and control $(P<0.005)$ levels. The stability of the plasma insulin concentration during the plateau period was essentially the same pre- and postdialysis and in the control group; coefficients of variation averaged $10.5 \pm 1.0,9.6 \pm 0.8$, and $10 \pm 1.6$, respectively. The mean plasma insulin concentrations over the entire 120 -min period are pre- sented in Table IV. The higher levels in subjects 2 , 9 , and 10 reflect the fact that the insulin infusion period was $120 \mathrm{~min}$ in these subjects, but was $80 \mathrm{~min}$ in the other subjects.

The MCR of insulin (insulin infusion rate divided by the increase above basal in the 20-80-min insulin concentration) increased by $29 \%$ postdialysis ( $P$ $<0.005$, Table IV). The MCR of the control group was $527 \pm 26$. Thus, on the average, the uremic patients predialysis had a somewhat lower MCR than controls; the increase in MCR postdialysis led to an average value somewhat higher than the control group, but neither of these differences were statistically significant.

The blood glucose concentration was maintained at a constant level during the period of hyperinsulinemia. The mean coefficients of variation pre- and postdialysis were $3.3 \pm 0.3$ and $3.6 \pm 0.3 \%$, respectively. The corresponding value in the control subjects was $4.8 \pm 0.4 \%$.

The amount of glucose metabolized (M) increased 
TABLE IV

Glucose Metabolism (M), Plasma Insulin Concentration, Insulin Sensitivity, and MCR during the Euglycemic Clamp Pre- and Postdialysis

\begin{tabular}{|c|c|c|c|c|c|c|c|c|c|c|}
\hline \multirow[b]{2}{*}{ Patient } & \multicolumn{3}{|c|}{$M(0-120 \mathrm{~min})$} & \multicolumn{3}{|c|}{$\begin{array}{l}\text { Plasma insulin conc. } \\
(0-120 \mathrm{~min})\end{array}$} & \multirow{2}{*}{$\begin{array}{l}\text { Percent increase } \\
\text { in insulin } \\
\text { sensitivity (M/I) }\end{array}$} & \multicolumn{3}{|c|}{$\mathrm{MCR}^{*}$} \\
\hline & Pre & Post & Change & Pre & Post & Change & & Pre & Post & Change \\
\hline & \multicolumn{2}{|c|}{$\mathrm{mg} / \mathrm{kg} / \mathrm{min}$} & $\%$ & \multicolumn{2}{|c|}{$\mu U / m l$} & $\%$ & $\%$ & \multicolumn{2}{|c|}{$\mathrm{ml} / \mathrm{min} / \mathrm{m}^{2}$} & $\%$ \\
\hline 1 & 3.09 & 2.98 & -4 & 80 & 70 & -13 & 10 & 452 & 620 & +37 \\
\hline 2 & 4.46 & 4.02 & -10 & 114 & 90 & -21 & 14 & 395 & 605 & +53 \\
\hline 3 & 4.56 & 4.53 & -1 & 89 & 88 & -1 & 1 & 411 & 405 & -2 \\
\hline 4 & 4.42 & 4.62 & 5 & 87 & 73 & -16 & 25 & 456 & 550 & +21 \\
\hline 5 & 2.58 & 3.98 & 54 & 81 & 55 & -32 & 127 & 441 & 791 & +79 \\
\hline 6 & 1.40 & 3.05 & 118 & 88 & 90 & 2 & 113 & 471 & 457 & -3 \\
\hline 7 & 2.24 & 2.60 & 16 & 72 & 58 & -19 & 44 & 524 & 678 & +29 \\
\hline 8 & 2.67 & 4.42 & 66 & 83 & 54 & -35 & 154 & 550 & 767 & +40 \\
\hline 9 & 3.67 & 4.48 & 18 & 136 & 107 & -21 & 55 & 388 & 476 & +23 \\
\hline 10 & 4.66 & 5.26 & 13 & 123 & 111 & -9 & 25 & 388 & 444 & +14 \\
\hline Mean & 3.37 & 3.99 & 28 & 95 & 80 & -17 & 57 & 448 & 579 & +29 \\
\hline$\pm \underset{P}{\mathrm{SEM}}$ & 0.36 & 0.27 & $\begin{array}{l}13 \\
<0.05\end{array}$ & 7 & 7 & $\begin{array}{c}4 \\
<0.005\end{array}$ & $\begin{array}{l}17 \\
<0.01\end{array}$ & 18 & 43 & $\begin{array}{c}9 \\
<0.005\end{array}$ \\
\hline
\end{tabular}

* Metabolic clearance rate $=$ Insulin infusion rate $\div($ Steady-state $[20-80 \mathrm{~min}]$ plasma insulin conc. - Basal plasma insulin conc.).

postdialysis from $3.37 \pm 0.36$ to $3.99 \pm 0.27 \mathrm{mg} / \mathrm{kg}$ per min $(P<0.05$, Table IV). The $\mathrm{M}$ of the control group was $4.24 \pm 0.22$, a value significantly greater than the uremics predialysis $(P<0.05)$ but not significantly different from the uremics postdialysis.

After dialysis tissue sensitivity to insulin (M/I) increased from $3.56 \pm 0.33$ to $5.23 \pm 0.48$ (in units of $\mathrm{mg} / \mathrm{kg}$ per min per $\mu \mathrm{U} / \mathrm{ml} \times 100$ ). In paired analysis the increase in sensitivity was statistically significant $(P$ $<0.01$, Table IV). Tissue sensitivity to insulin in the control group was $6.00 \pm 0.41$. Thus, the uremics predialysis were significantly less sensitive to insulin than normal $(P<0.005)$, and dialysis on the average corrected this defect.

In patients 9 and 10 basal glucose production averaged $3.06 \mathrm{mg} / \mathrm{kg}$ per min predialysis and fell to 0.50 $\mathrm{mg} / \mathrm{kg}$ per min during the euglycemic clamp. After dialysis basal glucose production was unchanged and a similar decline was observed after insulin (Table V).

\section{DISCUSSION}

Despite numerous investigations into the mechanisms underlying the glucose intolerance of uremia, a clear consensus has not emerged. The usual techniques for assessing glucose tolerance, oral and intravenous glucose administration, clearly demonstrate the intolerance; however, even with the monitoring of plasma insulin responses and use of the insulin/glucose ratio, definition of the mechanism(s) underlying the glucose intolerance is unclear. The glucose clamp technique offers a number of advantages over these clinical tests:

(a) The hyperglycemic stimulus to the beta cell is controlled; thus, repeated studies (pre- and postdialysis) of beta cell sensitivity can be accurately interpreted and compared to normal control subjects receiving an identical hyperglycemic stimulus.

(b) In the clinical tests the complex glucose-insulin feedback interaction (plasma glucose concentration stimulates insulin release which in turn lowers the glucose concentration) prohibits quantification of the sensitivity of body tissues to insulin; the glucose clamp, by controlling one of these variables and by

\section{TABLE V}

Effect of Insulin (Euglycemic Clamp) on Hepatic Glucose Production in Patients 9 and 10

\begin{tabular}{llllll}
\hline & \multicolumn{2}{c}{ Patient 9} & & \multicolumn{2}{c}{ Patient 10} \\
\cline { 2 - 3 } & $\begin{array}{c}\text { Pre- } \\
\text { dialysis }\end{array}$ & $\begin{array}{c}\text { Post- } \\
\text { dialysis }\end{array}$ & & $\begin{array}{c}\text { Pre- } \\
\text { dialysis }\end{array}$ & $\begin{array}{c}\text { Post- } \\
\text { dialysis }\end{array}$ \\
\hline $\begin{array}{l}\text { Basal glucose produc- } \\
\text { tion, } m g / k g / m i n\end{array}$ & 2.71 & 2.81 & & 3.42 & 3.43 \\
$\begin{array}{c}\text { Glucose production } \\
\text { post insulin, }\end{array}$ & 0.61 & 0.57 & & 0.40 & 0.52 \\
$\begin{array}{c}\text { mg/kg/min } \\
\begin{array}{l}\text { Decrease post- } \\
\text { insulin, \% }\end{array}\end{array}$ & 78 & 80 & & 88 & 85 \\
\hline
\end{tabular}


providing a measure of glucose metabolized, overcomes this problem.

(c) The euglycemic clamp technique offers advantages over the previously used technique for assessing "insulin sensitivity", the intravenous insulin tolerance test. By maintaining the basal glucose level after insulin administration, not only is the discomfort and potential hazard of hypoglycemic reactions prevented, but the complex neuro-endocrine response to hypoglycemia does not occur. The test thus provides a purer estimate of sensitivity to insulin. The establishment of a steady-state level of plasma insulin concentration also allows the calculation of the metabolic clearance rate of insulin.

(d) The hyperglycemic and euglycemic clamps provide independent tests of the sensitivity of the body to endogenously released and to exogenously administered insulin.

The role of impaired insulin secretion in the genesis of uremia-induced glucose intolerance has been the subject of many conflicting reports (19). The plasma concentrations of insulin achieved during the later phases of both the oral and intravenous glucose tolerance test have been reported to be elevated. However, these studies were not designed to determine whether the increased levels of insulin were the consequence of $(a)$ true hypersecretion of insulin, $(b)$ relative hypersecretion secondary to the higher glucose levels late in the test, $(c)$ the prolonged halflife of insulin that occurs in uremia, or $(d)$ a combination of these. The early phase of insulin release has been even less well characterized with various investigators reporting increased $(6,9)$, normal $(4,5,7,17)$, or decreased $(11,18)$ insulin secretion. Attempts to resolve this issue by utilizing the insulin/glucose ratio have been equally conflicting (19).

Under the condition of sustained, constant hyperglycemia, the plasma insulin response in uremic subjects was biphasic with an early burst of insulin followed by a gradually increasing phase of insulin release. This pattern has been previously described in man (26-28) and animal $(29,30)$. While the pattern of plasma insulin response to hyperglycemia in uremic patients predialysis was normal, the level of response was greater than normal afater the initial insulin peak. After dialysis the insulin response was reduced by $11 \%$ but this change was not statistically significant. Since the MCR of insulin increased after dialysis, this change in itself would cause a decrease in the plasma insulin level. It is of interest, therefore, to examine the quantitative aspects of the relation between plasma insulin level and MCR. This can be done by estimating the systemic (or posthepatic) delivery rate of insulin during the 2-h hyperglycemic period. The systemic delivery rate can be approximated from the product of the MCR and the mean plasma insulin concentration
(Table VI). Note that this computation can be carried out for each subject pre- and postdialysis by virtue of the fact that values for MCR are available from the euglycemic (insulin infusion) clamp and the plasma insulin response to hyperglycemia is available from the hyperglycemic clamp. The results show that the modest decrease in plasma insulin response postdialysis (Table III) is the result of a small increase (14\%) in systemic insulin delivery rate (Table VI) in conjunction with a significant increase $(32 \%)$ in the MCR (Table IV).

It should also be noted that the increase in MCR of insulin after dialysis occurred without change in renal function. Similar findings have been reported by Hampers et al (31) in anephric patients. These results suggest that inhibition of some insulin-degrading organ system other than the kidney occurs in uremia. Since the liver normally degrades $50 \%$ or more of the insulin released by the pancreas $(32,33)$, hyperinsulinemia (Fig. 2) could be explained by a defect in hepatic degradation. In support of this hypothesis Wildberger et al. (34) found that liver extracts of nephrotic rats inactivate less insulin than controls.

The individual variability in the change in beta cell response to glucose after dialysis is best understood when viewed in relation to the changes in tissue sensitivity to insulin. After dialysis a significant improvement in tissue sensitivity to insulin (M/I) occurred in seven of eight subjects studied with the hyperglycemic clamp (range $=33-230 \%$ ). These data suggest that the dominant factor contributing to the glucose intolerance of uremia is tissue resistance to the action of insulin. As dialysis corrects this insulin resistance, glucose tolerance improves despite either no change (patient 4) or even a decrease (patients $2,5,7$, and 8 ) in beta cell sensitivity to hyperglycemia (Table III).

TABLE VI

Systemic Delivery Rate (SDR) (0-120 min) in Insulin during the Hyperglycemic Clamp in Uremic Subjects Pre- and Postdialysis

\begin{tabular}{crrr}
\hline & \multicolumn{3}{c}{ SDR } \\
\cline { 2 - 4 } Patient & Pre & Post & Change \\
\hline \multicolumn{2}{c}{$m U / m$ in $^{2} m^{2}$} & $\%$ \\
1 & 31.1 & 63.5 & +104 \\
2 & 46.6 & 58.2 & +25 \\
3 & 25.8 & 29.0 & +12 \\
4 & 40.4 & 48.6 & +20 \\
5 & 51.1 & 40.7 & -20 \\
6 & 43.0 & 48.5 & +13 \\
7 & 50.6 & 54.2 & +7 \\
8 & 41.4 & 33.4 & -19 \\
Mean & 41.2 & 47.0 & 18 \\
SEM & 3.2 & 4.2 & 14 \\
\hline
\end{tabular}




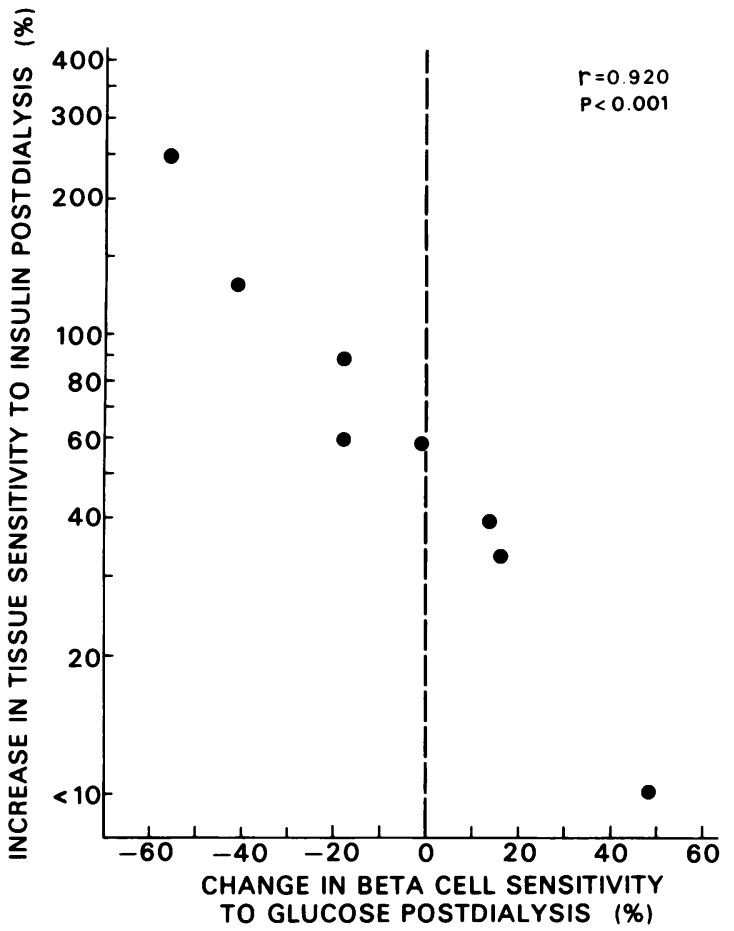

Figure 4 Correlation between the changes in beta cell sensitivity to glucose and log tissue sensitivity to insulin postdialysis.

However, it is clear that in some subjects a defect in insulin response contributes to the glucose intolerance. In patient 1 , glucose metabolism improved by $50 \%$, yet tissue sensitivity to insulin improved by only $2 \%$
(Table III). Here the improvement in glucose tolerance after dialysis was entirely attributable to an increase in insulin response. In two other subjects (nos. 3 and 6), both an increased insulin response and enhanced tissue sensitivity contributed to the improvement in glucose tolerance after dialysis. The change in tissue sensitivity to insulin after dialysis is strongly inversely correlated with the log change in beta cell sensitivity to glucose (Fig. 4) $(r=-0.920 ; P<0.001)$. Those individuals who showed the most improvement in tissue sensitivity to insulin (left of dashed line) actually decreased their plasma insulin response to hyperglycemia; those whose improvement in tissue sensitivity was more modest (right of dashed line) showed increases in beta cell response.

Because all 10 subjects received euglycemic clamp studies pre- and postdialysis, independent measures of sensitivity to insulin are available and the results of the estimates on the two types of clamps can be compared. In the euglycemic studies, improvement in sensitivity occurred in 9 of 10 subjects and averaged $57 \%$; this value agrees well with the mean improvement seen in the hyperglycemic clamp, $80 \%$. A comparison of the estimates of improvement after dialysis in tissue sensitivity to insulin with the two types of clamps can be seen in Fig. 5. In general, the improvements in insulin sensitivity in individual subjects by the two techniques agree well. This agreement between the two clamps was tested for statistical significance by correlating the logarithms of the percent change in $M / I$ postdialysis for the two clamps; the $r$ value of 0.874 is significant at $P=0.01$.

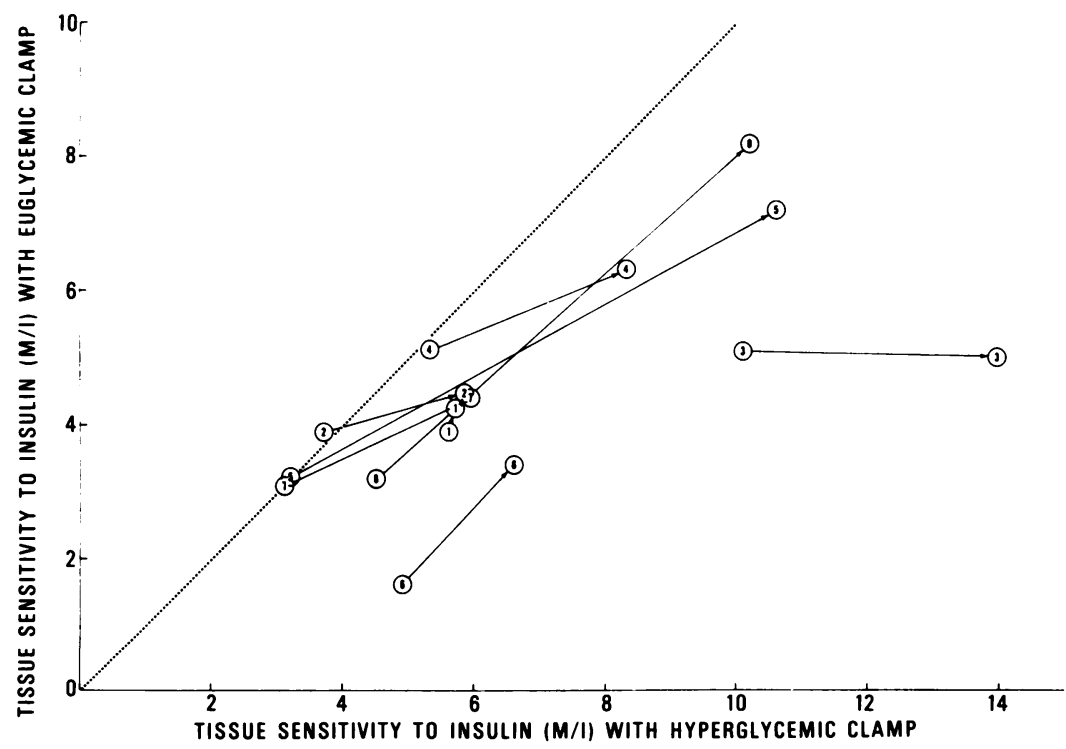

FIGURE 5 Change in tissue sensitivity to insulin (M/I) postdialysis estimated by the hyperglycemic and the euglycemic clamp. The paired numbered circles identify the individual subjects and show results predialysis and postdialysis. The arrows indicate the direction of change from the predialysis to the postdialysis state. 
Insulin resistance in uremia could result from decreased tissue uptake of glucose or augmented hepatic glucose production, which is incompletely suppressed by insulin. The results of the glucose turnover studies in patients 9 and 10 suggest that the liver in uremia is normally responsive to insulin and that the improvement in tissue sensitivity observed after dialysis is the result of enhanced glucose uptake by peripheral tissues. These results are in agreement with a recent report by Mondon et al. (35) who observed normal suppression of hepatic glucose production by insulin in uremic rats and impairment of glucose uptake by the perfused hindlimb.

Numerous factors have been implicated in the pathogenesis of the carbohydrate intolerance of uremia and these have been the subject of a recent review (19). None of our patients had significant hypokalemia, hypermagnesemia, or acidosis (Table I). There was no correlation between the type of renal disease and the presence of glucose intolerance. All subjects had long-standing, severe renal insufficiency. All were free of gastrointestinal symptoms, were on weight maintaining diets, and manifested no clinical evidence of malnutrition. Mild hypoalbuminemia (average serum albumin $=3.2 \pm 0.2 \mathrm{~g} / \mathrm{dl}$ ) was present predialysis. However, glucose intolerance improved postdialysis without change in serum albumin $(3.4 \pm 0.2 \mathrm{~g} / \mathrm{dl})$. Elevated plasma levels of growth hormone $(5,8,9,36-$ $39)$ and glucagon $(40,41)$ have been implicated in the glucose intolerance of uremia. Glucagon was not evaluated in the present study, but hepatic glucose production was normally suppressed by insulin in the two patients in whom it was examined. We were able to correct the glucose intolerance despite persistently elevated growth hormone levels (unpublished observations).

\section{ACKNOWLEDGMENTS}

We wish to thank Doctors Daniel Sapir and Jimmie Zachary for referring the patients to us for study. Ms. Mary Elizabeth Bannon, Ms. Faye E. Barrack, and Mr. Howard Baldwin provided excellent technical assistance and Ms. Annette L. Watts provided excellent secretarial assistance.

This work was supported, in part, by National Institutes of Health contract AM 42221 and grant RR125.

\section{REFERENCES}

1. Westervelt, F. B. 1968. Abnormal carbohydrate metabolism in uremia. Am. J. Clin. Nutr. 21 : 423-425.

2. Westervelt, F. B. 1969. Insulin effect in uremia. J. Lab. Clin. Med. 74: 79-84.

3. Westervelt, F. B. 1970. Uremia and insulin response. Arch. Intern. Med. 126: 865-869.

4. Cerletty, J. M., and H. H. Engbring. 1967. Azotemia and glucose intolerance. Ann. Intern. Med. 66: 1097-1108.

5. Horton, E. S., C. Johnson, and H. E. Lebevitz. 1968. Carbohydrate metabolism in uremia. Ann. Intern. Med. 68: 63-74.
6. Hutchings, R. H., R. M. Hegstrom, and B. H. Scribner. 1966. Glucose intolerance in patients on long-term intermittent dialysis. Ann. Intern. Med. 65: 275-285.

7. Lowrie, E. G., J. S. Soeldner, C. L. Hampers, and J. P. Merrill. 1970. Glucose metabolism and insulin secretion in uremic, prediabetic, and normal subjects. J. Lab. Clin. Med. 76: 603-615.

8. Samaan, N. A., and R. M. Freeman. 1970. Growth hormone levels in severe renal failure. Metab. Clin. Exp. 19: $102-113$.

9. Spitz, I. M., A. H. Rubenstein, I. Bersohn, C. Abrahams, and C. Lowry. 1970. Carbohydrate metabolism in renal disease. Q. J. Med. 39: 201-226.

10. Chamberlain, M. J., and L. Stimmler. 1967. The renal handling of insulin. J. Clin. Invest. 46: 911-919.

11. Hampers, C. L., J. S. Soeldner, P. B. Doak, and J. P. Merrill. 1966. Effect of chronic renal failure and hemodialysis on carbohydrate metabolism. J. Clin. Invest. 45: 1719-1731.

12. Perkoff, G. T., C. L. Thomas, J. D. Newton, J. C. Sellman, and F. H. Tyler. 1958. Mechanism of impaired glucose tolerance in uremia and experimental hyperazotemia. Diabetes. 7: 375-383.

13. Westervelt, F. B., and G. E. Schreiner. 1962. The carbohydrate intolerance of uremic patients. Ann. Intern. Med. 57: 266-276.

14. Teuscher, V. A., S. Frankhauser, and F. R. Kuffer. 1963. Studies on carbohydrate metabolism in renal insufficiency. Klin. Wochenschr. 41: 706-715.

15. Teuscher, V. A. 1964. Beurteilung der Blutzuckerwerte und der Glukosetoleranz bei Uramie. Schweiz. Med. Wochenschr. 94: 69-74.

16. Cohen, B. D., and H. I. Horowitz. 1968. Carbohydrate metabolism in uremia: Inhibition of phosphate release. Am. J. Clin. Nutr. 21: 407-413.

17. Briggs, J. D., K. D. Buchanan, R. G. Luke, and M. T. McKiddie. 1967. Role of insulin in glucose intolerance in uremia. Lancet. I: 462-464.

18. Hampers, C. L., J. S. Soeldner, R. E. Gleason, G. L. Bailey, J. H. Diamond, and J. P. Merrill. 1968. Insulin-glucose relationship in uremia. Am. J. Clin. Nutr. 21: 414-422.

19. DeFronzo, R. A., R. Andres, P. Edgar, and G. W. Walker. 1973. Carbohydrate metabolism in uremia: a review. Medicine (Baltimore). 52: 469-481.

20. Andres, R. 1971. Aging and diabetes. Med. Clin. N. Am. 55: 835-846.

21. Sherwin, R. S., K. J. Kramer, J. D. Tobin, P. A. Insel, J. E. Liljenquist, M. Berman, and R. Andres. 1974. A model of the kinetics of insulin in man. J. Clin. Invest. 53: $1481-1492$.

22. Steele, R. 1959. Influence of glucose loading and of injected insulin on hepatic glucose output. Ann. N. Y. Acad. Sci. 82: 420-430.

23. Cowan, J. S. and G. Hetenyi. 1971. Glucoregulatory responses in normal and diabetic dogs recorded by a new tracer method. Metab. Clin. Exp. 20: 360-372.

24. Radziuk, J., K. H. Norwich, and M. Vranic. 1974. Measurement and validation of nonsteady state turnover rates with application to the insulin and glucose systems. Fed. Proc. 33: 1855-1864.

25. Sherwin, R. S., R. Hendler, R. A. DeFronzo, J. Wahren, and P. Felig. 1977. Glucose homeostasis during prolonged suppression of glucagon and insulin secretion by somatostatin. Proc. Natl. Acad. Sci. U. S. A. 74: 348-352.

26. Porte, D., and A. A. Pupo. 1969. Insulin responses to glucose: Evidence for a two pool system in man. J. Clin. Invest. 48: 2309-2319.

27. Cerasi, E. 1967. An analogue computer model for the 
insulin response to glucose infusion. Acta Endocrinol. 55: 163-183.

28. Andres, R., T. Pozefsky, R. S. Swerdloff, and J. D. Tobin. 1970. Effect of aging on carbohydrate metabolism. In Early Diabetes. R. Camerini-Davalos and H. S. Cole, editors. Academic Press, Inc., New York. 349-355.

29. Curry, D. L., L. L. Bennett, and G. M. Grodsky. 1968. Dynamics of insulin secretion by the perfused rat pancreas. Endocrinology. 83: 572-584.

30. Grodsky, G. M. 1972. A threshold distribution hypothesis for packet storage of insulin and its mathematical modeling. J. Clin. Invest. 51: 2047-2059.

31. Hampers, C. L., E. G. Lowrie, J. S. Soeldner, and J. P. Merrill. 1970. The effect of uremia upon glucose metabolism. Arch. Intern. Med. 126: 870-874.

32. Blackard, W. G., and N. C. Nelson. 1971. Portal vein insulin concentration in diabetic subjects. Diabetes. 20: 286-288.

3.3. Madison, L. L., B. Combes, and R. H. Unger. 1958. The relationship between the mechanism of action of the sulfonylureas and the secretion of insulin into the portal circulation. Ann. N. Y. Acad. Sci. 74: 548-556.

34. Wildberger, H. L., H. T. Ricketts, and L. Regut. 1963. Degradation of insulin by tissue extracts of normal and nephrotic rats. Proc. Soc. Exp. Biol. Med. 112: 168-170.

35. Mondon, C., C. Dolkas, and G. Reaven. 1977. Mechanism of impaired glucose tolerance in acute uremia. Diabetes. 26(Suppl. 1): 375.

36. Tchobroutsky, G., G. Rosselin, R. Assan, and M. Derot. 1969. Glucose intolerance in uremia. Diabetologia. 5: 25-28.

37. Wright, A. D., C. Lowry, T. R. Fraser, I. M. Spitz, A. H. Rubenstein, and I. Bersohn. 1968. Serum growth hormone and glucose intolerance in renal failure. Lancet. II: 798-800.

38. Gonzalez, A. R., R. C. Khurana, Y. Jung, E. Livstone, A. Wolinsky, C. Sinclair, and T. S. Danowski. 1972. Enhanced response to tolbutamide in uremia. Acta Diabetol. Lat. 9: 373-386.

39. Orskov, H., and N. J. Christensen. 1971. Growth hormone in uremia. Scand. J. Clin. Lab. Invest. 27: 51-60.

40. Bilbrey, G. L., G. R. Faloona, M. G. White, and J. P. Knochel. 1974. Hyperglucagonemia of renal failure. J. Clin. Invest. 53: 841-847.

41. Sherwin, R., C. Bastl, F. Finkelstein, M. Fisher, H. Black, R. Hendler, and P. Felig. 1976. Influence of uremia and hemodialysis on the turnover and metabolic effects of glucagon. J. Clin. Invest. 57: 722-731. 